\title{
A Selective Turn-On Fluorescent Sensor for Imaging Copper in Living Cells
}

\author{
Li Zeng, ${ }^{\dagger}$ Evan W. Miller, ${ }^{\dagger}$ Arnd Pralle, ${ }^{\ddagger}$ Ehud Y. Isacoff, ${ }^{\ddagger}$ and Christopher J. Chang*, ${ }^{*}$ \\ Departments of ${ }^{\dagger}$ Chemistry and ${ }^{\ddagger}$ Molecular and Cell Biology, University of California, Berkeley, \\ CA 94720
}

Synthetic Materials and Methods. Silica gel 60 (230-400 mesh, Fisher) was used for column chromatography. Analytical thin layer chromatography was performed using Fisher 60 F254 silica gel (precoated sheets, $0.25 \mathrm{~mm}$ thick). Chloroacetyl chloride, thiourea, bis(2chloroethyl)amine hydrochloride, and rhodamine 101 inner salt were purchased from Acros Organics (Morris Plains, NJ) and were used as received. Cesium carbonate was purchased from Alfa Aesar (Ward Hill, MA) and was used as received. All other chemicals were purchased from Sigma-Aldrich (St. Louis, MO) and were used as received. ${ }^{1} \mathrm{H}$ NMR spectra were collected in $\mathrm{CDCl}_{3}$ (Cambridge Isotope Laboratories, Cambridge, MA) at $25^{\circ} \mathrm{C}$ on a Bruker AV-300 or AV400 spectrometer at the College of Chemistry NMR Facility at the University of California, Berkeley. All chemical shifts are reported in the standard $\delta$ notation of parts per million using the peak of residual proton and carbon signals of $\mathrm{CDCl}_{3}$ as internal reference: $\delta 7.26$ for ${ }^{1} \mathrm{H}$. Highresolution mass spectral analyses were carried out at the College of Chemistry Mass Spectrometry Facility at the University of California, Berkeley.

\section{8-Chloromethyl-2,6-diethyl-4,4-difluoro-1,3,5,7-tetramethyl-4-bora-3a,4a-diaza-s-indacene} (1). The BODIPY compound was synthesized according to a modified literature procedure. ${ }^{1}$ Chloroacetyl chloride $(0.91 \mathrm{~g}, 8.1 \mathrm{mmol})$ and 2,4-dimethyl-3-ethylpyrrole $(1.99 \mathrm{~g}, 16.2 \mathrm{mmol})$ were added to dichloromethane $(100 \mathrm{~mL})$ degassed under a nitrogen atmosphere. The reaction mixture was stirred at $50{ }^{\circ} \mathrm{C}$ for $2 \mathrm{~h}$ for under nitrogen and the solvent was removed by rotary evaporation. Toluene $(190 \mathrm{~mL})$, dichloromethane $(10 \mathrm{~mL})$, and triethylamine $(5.4 \mathrm{~mL}, 3.92 \mathrm{~g}$, $38.4 \mathrm{mmol}$ ) were added to the residue and the resulting mixture was stirred at room temperature for $30 \mathrm{~min}$. Boron trifluoride diethyl etherate $(7.0 \mathrm{~mL}, 7.90 \mathrm{~g}, 55.6 \mathrm{mmol})$ was then added, and the reaction mixture was stirred for $2 \mathrm{~h}$ at $50{ }^{\circ} \mathrm{C}$. The solvents were removed under reduced pressure and the residue was taken up in dichloromethane $(200 \mathrm{~mL})$. The organic phase was washed with water $(100 \mathrm{~mL})$, dried over $\mathrm{Na}_{2} \mathrm{SO}_{4}$, and evaporated to dryness. Purification by flash column chromatography (silica gel, 3:1 toluene/hexanes) followed by recrystallization from hexanes (300 mL) at $-78{ }^{\circ} \mathrm{C}$ afforded 1 as a dark red solid (455 mg, 16\% yield). ${ }^{1} \mathrm{H}$ NMR $\left(\mathrm{CDCl}_{3}, 300 \mathrm{MHz}\right): \delta 4.82(2 \mathrm{H}, \mathrm{s}), 2.50(6 \mathrm{H}, \mathrm{s}), 2.45(6 \mathrm{H}, \mathrm{s}), 2.40(4 \mathrm{H}, \mathrm{q}, J=7.5 \mathrm{~Hz}), 1.05(6 \mathrm{H}$, $\mathrm{t}, J=7.5 \mathrm{~Hz})$. FAB-MS: calculated for $\left[\mathrm{M}^{+}\right]$352, found 352 .

3-Thiapentan-1-thiol (2). Compound 2 was prepared using a different synthetic strategy than described in the literature. ${ }^{2}$ A mixture of ethyl 2-hydroxyethyl sulfide $(4.25 \mathrm{~g}, 40 \mathrm{mmol})$ and thiourea (3.05 g, $40 \mathrm{mmol}$ ) in $48 \%$ hydrobromic acid $(8.5 \mathrm{~mL}, 75 \mathrm{mmol}$ ) was refluxed overnight under nitrogen. The reaction was cooled to room temperature, concentrated aq. $\mathrm{NaOH}$ ( $3.2 \mathrm{~g}, 80$ mmol) was added carefully, and the resulting mixture was refluxed overnight under nitrogen. The reaction then was cooled to room temperature, neutralized with concentrated $\mathrm{HCl}$, and extracted with dichloromethane $(100 \mathrm{~mL})$. The organic phase was separated, washed with water (100 mL), dried over $\mathrm{Na}_{2} \mathrm{SO}_{4}$, and evaporated to dryness to furnish 2 as a colorless, pungent oil that was used without purification ( $4.1 \mathrm{~g}, 84 \%$ yield). ${ }^{1} \mathrm{H}$ NMR $\left(\mathrm{CDCl}_{3}, 400 \mathrm{MHz}\right): \delta 2.66-2.81$ 
(4H, m), $2.56(2 \mathrm{H}, \mathrm{q}, J=7.2 \mathrm{~Hz}), 1.73(1 \mathrm{H}, \mathrm{t}, J=7.2 \mathrm{~Hz}), 1.25$ (3H, t, $J=7.2 \mathrm{~Hz})$. EI-MS: calculated for $\left[\mathrm{MH}^{+}\right] 123$, found 123 .

3,6,12,15-Tetrathia-9-monoazaheptadecane (3). Compound 3 was synthesized according to a modified literature procedure. ${ }^{3}$ Under a nitrogen atmosphere, sodium (1.29 g, $\left.56 \mathrm{mmol}\right)$ and 3thiapentan-1-thiol $(4.1 \mathrm{~g}, 33.6 \mathrm{mmol})$ were added to absolute ethanol $(60 \mathrm{~mL})$ and the resulting solution was heated to reflux. A solution of bis(2-chloroethyl)amine hydrochloride (2.0 g, 11.2 mmol) in absolute ethanol $(35 \mathrm{~mL})$ was then added dropwise to the thiolate solution and the resulting mixture was refluxed for $4 \mathrm{~h}$. The solvent was removed by rotary evaporation and the residue was taken up in chloroform $(200 \mathrm{~mL})$. The organic phase was then washed with water, dried over $\mathrm{Na}_{2} \mathrm{SO}_{4}$, and the solvent was removed by rotary evaporation. Purification by flash column chromatography (silica gel, 10\% methanol/dichloromethane) gave $\mathbf{3}$ as a viscous light brown oil (2.75 g, 79\% yield). ${ }^{1} \mathrm{H}$ NMR $\left(\mathrm{CDCl}_{3}, 300 \mathrm{MHz}\right): \delta 2.81$ (4H, t, $\left.J=6.5 \mathrm{~Hz}\right), 2.64-2.75$ $(12 \mathrm{H}, \mathrm{m}), 2.52(4 \mathrm{H}, \mathrm{q}, J=7.2 \mathrm{~Hz}), 1.79(1 \mathrm{H}, \mathrm{br}) 1.22(6 \mathrm{H}, \mathrm{t}, J=7.2 \mathrm{~Hz})$. FAB-MS: calculated for $\left[\mathrm{MH}^{+}\right] 314$, found 314 .

8-[N,N-Bis(3',6'-dithiaoctyl)-aminomethyl]-2,6-diethyl-4,4-difluoro-1,3,5,7-tetramethyl-4bora-3a,4a-diaza-s-indacene (Coppersensor-1, CS1, 4). A suspension of 1 (71 mg, 0.20 $\mathrm{mmol}$ ), 3 (125 mg, $0.40 \mathrm{mmol}$ ), KI (73 mg, $0.44 \mathrm{mmol}$ ), and $\mathrm{K}_{2} \mathrm{CO}_{3}(61 \mathrm{mg}, 0.44 \mathrm{mmol}$ ) in dry $\mathrm{CH}_{3} \mathrm{CN}(20 \mathrm{~mL})$ was refluxed overnight under nitrogen. The solvent was removed under reduced pressure and the residue was taken up in dichloromethane $(100 \mathrm{~mL})$. The organic phase was then washed with water, dried over $\mathrm{Na}_{2} \mathrm{SO}_{4}$, and evaporated to dryness. Purification by flash column chromatography (silica gel, dichloromethane) delivered $\mathbf{4}$ as a bright red solid (26 mg, 22\% yield). ${ }^{1} \mathrm{H}$ NMR ( $\left.\mathrm{CDCl}_{3}, 400 \mathrm{MHz}\right): \delta 4.02(2 \mathrm{H}, \mathrm{s}), 2.87(4 \mathrm{H}, \mathrm{t}, J=7.6 \mathrm{~Hz}), 2.52-2.65(16 \mathrm{H}, \mathrm{m})$, 2.50 (s, 6H), 2.40 (s, 6H), $2.38(4 \mathrm{H}, \mathrm{q}, J=7.6 \mathrm{~Hz}), 1.24(6 \mathrm{H}, \mathrm{t}, J=7.6 \mathrm{~Hz}) 1.05(6 \mathrm{H}, \mathrm{t}, J=7.6$ $\mathrm{Hz}$ ). FAB-MS: calculated for $\left[\mathrm{MH}^{+}\right] 630$, found 630 .

3,6,12,15-Tetrathia-9-monoazaheptadecane (5). A suspension of 3 (250 $\mathrm{mg}, 0.80 \mathrm{mmol})$, iodoethane (125 mg, $0.80 \mathrm{mmol}$ ), and $\mathrm{Cs}_{2} \mathrm{CO}_{3}(287 \mathrm{mg}, 0.88 \mathrm{mmol})$ in $\mathrm{DMF}(25 \mathrm{~mL})$ was stirred at $80{ }^{\circ} \mathrm{C}$ overnight under nitrogen. The solvent was removed under reduced pressure and the residue was taken up in dichloromethane $(100 \mathrm{~mL})$. The organic phase was then washed with water, dried over $\mathrm{Na}_{2} \mathrm{SO}_{4}$, and the solvent was removed by rotary evaporation. Purification by flash column chromatography (silica gel, 2\% ethyl acetate/dichloromethane) afforded $\mathbf{5}$ as a colorless oil (60 mg, $22 \%$ yield). ${ }^{1} \mathrm{H}$ NMR $\left(\mathrm{CDCl}_{3}, 300 \mathrm{MHz}\right): \delta 4.10(2 \mathrm{H}, \mathrm{q}, J=7.2 \mathrm{~Hz}), 3.30-$ $3.48(4 \mathrm{H}, \mathrm{m}), 2.58-2.78(12 \mathrm{H}, \mathrm{m}), 2.52(4 \mathrm{H}, \mathrm{q}, J=7.2 \mathrm{~Hz}), 1.22(9 \mathrm{H}, \mathrm{t}, J=7.2 \mathrm{~Hz})$.

Spectroscopic Materials and Methods. Millipore water was used to prepare all aqueous solutions. All spectroscopic measurements were performed in $20 \mathrm{mM}$ HEPES buffer, pH 7. Absorption spectra were recorded on a Varian Cary 50 spectrophotometer (Walnut Creek, CA) and fluorescence spectra were recorded on either a Jobin-Yvon SPEX FluoroMax-2 scanning spectrofluorometer (Edison, NJ) or a Photon Technology International Quanta Master 4 L-format scanning spectrofluorometer (Lawrenceville, NJ) equipped with an LPS-220B 75-W xenon lamp and power supply, A-1010B lamp housing with integrated igniter, switchable 814 photoncounting/analog photomultiplier detection unit, and MD5020 motor driver. Samples for absorption and emission measurements were contained in $1-\mathrm{cm} \times 1$-cm quartz cuvettes $(3.5-\mathrm{mL}$ volume, Starna, Atascadero, CA). Fluorescence quantum yields were determined by reference to 
rhodamine 101 inner salt in methanol $(\Phi=1.0)^{4}{ }^{4}$

The binding affinity of $\mathrm{Cu}^{+}$to CS1 was measured using thiourea as a competitive ligand to provide a buffered $\mathrm{Cu}^{+}$solution. Stability constants for thiourea binding were taken from the literature: $\beta_{12}=2.0 \times 10^{12}, \beta_{13}=2.0 \times 10^{14}, \beta_{14}=3.4 \times 10^{15} \cdot \mathrm{Cu}(\mathrm{I})$ was delivered in the form of $\left[\mathrm{Cu}(\mathrm{MeCN})_{4}\right]\left[\mathrm{PF}_{6}\right]$ from an acetonitrile stock solution $(20 \mathrm{mM})$. Measurements were carried out in $20 \mathrm{mM}$ HEPES, pH 7. Excitation was provided at $540 \mathrm{~nm}$, and collected emission was integrated from 550 to $700 \mathrm{~nm}$. The apparent dissociation constant $\left(K_{\mathrm{d}}\right)$ was determined using the following equation: $\left(\mathrm{F}-\mathrm{F}_{\min }\right) /\left(\mathrm{F}_{\max }-\mathrm{F}_{\min }\right)=\left[\mathrm{Cu}^{+}\right] /\left(\mathrm{K}_{\mathrm{d}}+\left[\mathrm{Cu}^{+}\right]\right)$, where $\mathrm{F}$ is the observed fluorescence, $\mathrm{F}_{\max }$ is the fluorescence for the $\mathrm{Cu}^{+}: \mathrm{CS} 1$ complex, and $\mathrm{F}_{\min }$ is the fluorescence for the free CS1 dye.

Preparation and Staining of Cell Cultures. HEK 293T cells were cultured in Dulbecco's Modified Eagle Medium (DMEM, Invitrogen, Carlsbad, CA) supplemented with 10\% Fetal Bovine Serum (FBS, Invitrogen), glutamine (2 mM), and penicillin/streptomycin (50 $\mu \mathrm{g} / \mathrm{mL}$, Invitrogen). One day before imaging, cells were passed and plated on 18-mm glass coverslips coated with poly-L-lysine (50 $\mu \mathrm{g} / \mathrm{mL}$, Sigma, St. Louis, MO). Immediately before the experiments, cells were washed with PBS buffer, incubated with the probe in PBS, washed, and imaged. Experiments to assess copper uptake were performed in the same media supplemented with $200 \mu \mathrm{M} \mathrm{CuCl}_{2}$.

Fluorescence Imaging Experiments. Confocal fluorescence imaging was performed with a Zeiss LSM510 NLO Axiovert 200 laser scanning microscope and a 40x oil-immersion objective lens. Excitation of CS1-loaded cells at $543 \mathrm{~nm}$ was carried out with a HeNe laser, and emission was collected using a $560 \mathrm{~nm}$ longpass filter. CS1 $(5 \mu \mathrm{M})$ was incubated with live cell samples for 5 min at $25^{\circ} \mathrm{C}$. Additions of the 3,6,12,15-tetrathia-9-monoazaheptadecane 5 to cell samples were performed directly on the microscope stage by bath application to the media.

\section{References}

1. Amat-Guerri, F.; Liras, M.; Carrascoso, M. L.; Sastre, R. Photochem. Photobiol. 2003, 77, 577-584.

2. Wolf, R. E.; Hartman, J. A. R.; Storey, J. M. E.; Foxman, B. M.; Cooper, S. R. J. Am. Chem. Soc. 1987, 109, 4328-4335.

3. Tanaka, M.; Nakamura, M.; Ikeda, T.; Ikeda, K.; Ando, H.; Shibutani, Y.; Yajima, S.; Kimura, K. J. Org. Chem. 2001, 66, 7008-7012.

4. Karstens, T.; Kobs, K. J. Phys. Chem. 1980, 84, 1871-1872.

5. Martell, A. E.; Smith, R. M. Critical Stability Constants, Plenum Press: New York, 1989. 

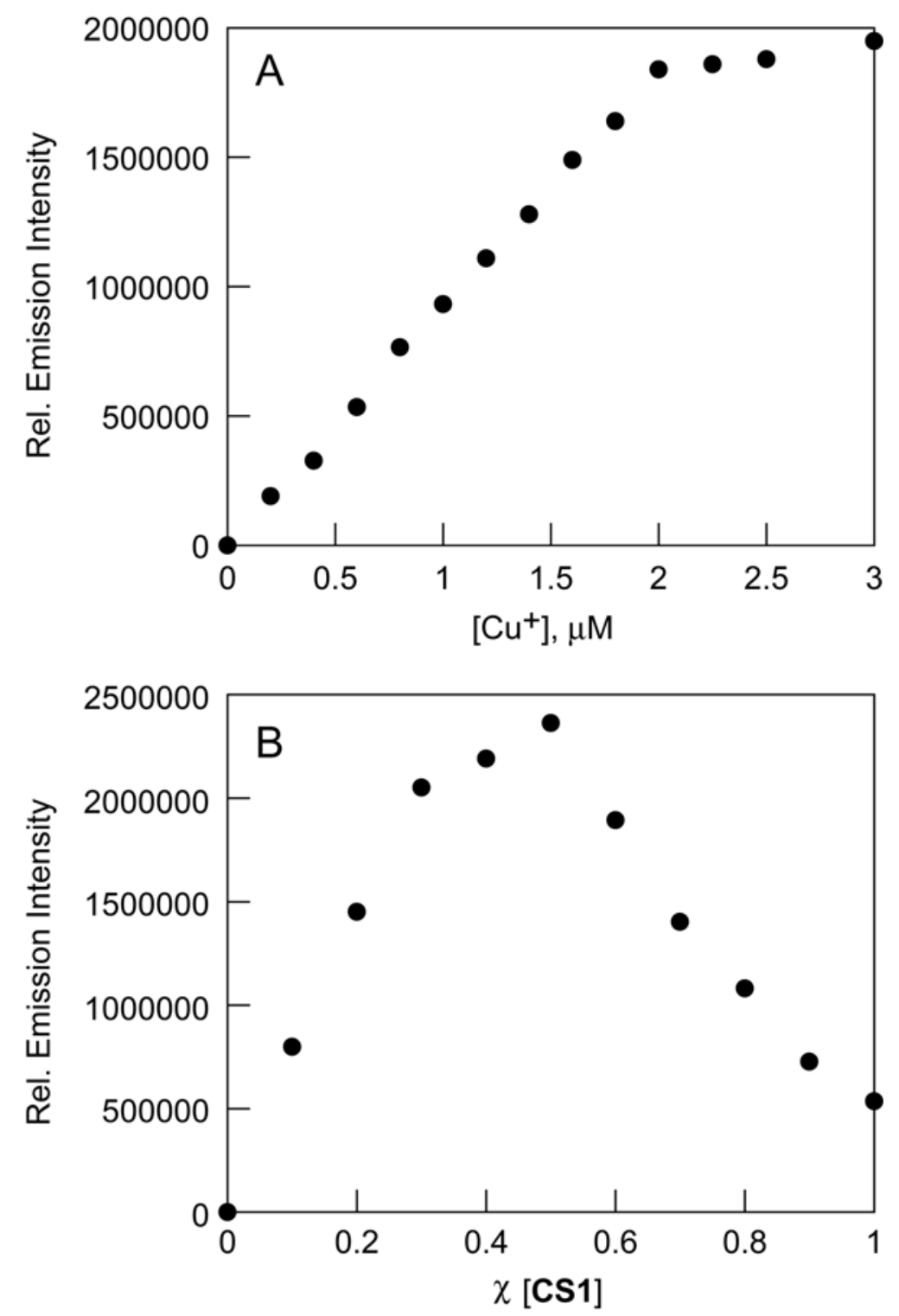

Figure S1. (A) Normalized fluorescence response of $2 \mu \mathrm{M} \mathrm{CS1} \mathrm{to} \mathrm{Cu}^{+}$. Excitation was provided at $540 \mathrm{~nm}$ and emission intensity was measured at $562 \mathrm{~nm}$. Spectra were acquired in $20 \mathrm{mM}$ HEPES, $\mathrm{pH}$ 7. The break at $2 \mu \mathrm{M}$ added $\mathrm{Cu}^{+}$(1 equiv) is consistent with formation of a $1: 1$ $\mathrm{Cu}^{+}: \mathrm{CS} 1$ complex. (B) Job's plot of CS1 and $\mathrm{Cu}^{+}$. The total concentration of CS1 and $\mathrm{Cu}^{+}$were kept at a constant $2 \mu \mathrm{M}$. Excitation was provided at $540 \mathrm{~nm}$ and emission intensity was measured at $562 \mathrm{~nm}$. Spectra were acquired in $20 \mathrm{mM}$ HEPES, $\mathrm{pH}$ 7. The maximum fluorescence response at $0.5 \mathrm{~mol}$ fraction of CS1 indicates formation of a $1: 1 \mathrm{Cu}^{+}: \mathrm{CS} 1$ complex. 


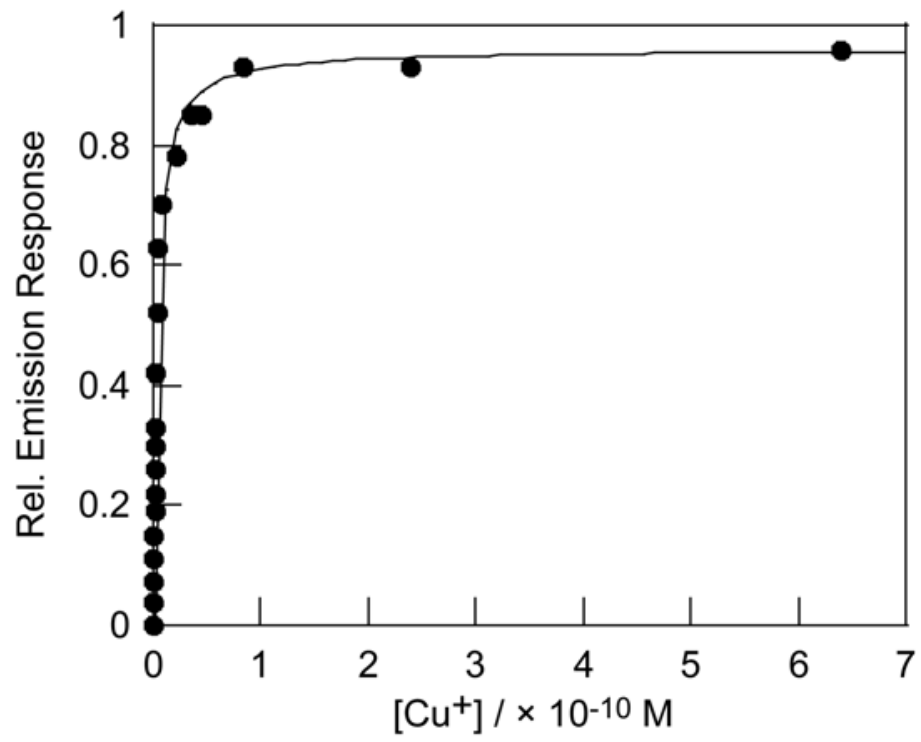

Figure S2. Normalized fluorescence response of $1 \mu \mathrm{M}$ CS1 to buffered $\mathrm{Cu}^{+}$solutions for $K_{\mathrm{d}}$ value determination. Thiourea was used as the competing ligand. Excitation was provided at 540 $\mathrm{nm}$ and the collected emission was integrated from 550 to $700 \mathrm{~nm}$. Spectra were acquired in 20 $\mathrm{mM}$ HEPES, $\mathrm{pH}$ 7. The points shown are for free $\mathrm{Cu}^{+}$buffered at $0,0.22,0.43,0.65,0.87,1.1$, 1.3, 1.5, 1.8, 2.1, 2.3, 3.2, 4.5, 8.6, 21.0, 36.0, 44.0, 83.0, 240, and 640 pM, respectively. The observed $K_{\mathrm{d}}$ value is $3.6(0.3) \times 10^{-12} \mathrm{M}$. 